\title{
Road traffic-related injury among the 0-17 age group in Turkey
}

\author{
Türkiye'de 0-17 yaş grubunda trafik kazalarına bağlı ölüm ve yaralanmalar
}

\author{
Cavit Işık YAVUZ, Onur HAMZAOĞLU
}

\section{BACKGROUND}

This study aimed to examine the extent of death and injuries among the 0-17 years of age group recorded in the official road traffic injury statistics.

\section{METHODS}

This is a record-based study covering a 5-year-period (2003-2007) using the annual records of national road traffic injury statistics in Turkey.

\section{RESULTS}

The $0-17$ age group accounted for $10.9 \%$ of deaths and $20.1 \%$ of injuries over the 5 -year-period that served as the scope of the study. It was found out that $53.5 \%$ of deaths and $70.7 \%$ of injuries occurred in residential areas. The occurrence of death among pedestrians in residential areas is notable. Injuries showed a similar tendency.

\section{CONCLUSION}

According to the 5-year period statistics examined in this study, road traffic-related deaths and injuries are a public health problem, and necessitate the development of programs and policies aimed at their prevention.

Key Words: Adolescent; child; road traffic injury.

\section{$A M A C$}

Bu çalışma, Türkiye'deki trafik kazası istatistiklerinde 0-17 yaş ölüm ve yaralanmalarının boyutunu incelemeyi amaçlamaktadır.

\section{GEREÇ VE YÖNTEM}

Çalışma trafik kaza istatistik yıllıklarından 2003-2007 yıllarına ilişkin beş yıllık dönemi kapsayan kayıt tabanlı bir incelemedir.

\section{BULGULAR}

Çalışma kapsamında incelenen beş yılık periyotta meydana gelen ölümlerin $\% 10,88$ 'ini ve yaralanmaların $\% 20,05$ 'ini 0-17 yaş grubu oluşturmaktadır. Bu ölümlerin \%53,54'ü, yaralanmaların \% 70,65 'i yerleşim yerlerinde meydana gelmiştir. Yerleşim yerleri ölümlerinde yaya, yerleşim yeri dış1 ölümlerde ise yolcu ölümleri dikkat çekmektedir. Yaralanmalarda da benzerlik vardır.

\section{SONUÇ}

İncelenen beş yıllık istatistiklere göre Türkiye'de 0-17 yaş grubuna ilişkin trafik kazalarından kaynaklanan ölüm ve yaralanmalar, koruyucu politika ve programlar geliştirilmesini gerektiren bir halk sağlığı sorunudur.

Anahtar Sözcükler: Ergen; çocuk; trafik kazaları.
Road traffic-related injuries are never-ending and can cause serious public health problems. According to the data gathered from WHO (World Health Organization), deaths related to road traffic injuries account for $25 \%$ of all injury-related deaths. Road traffic accidents, causing the death of 1.2 million and injury in 50 million people throughout the world, are predicted to show an increase of $65 \%$ in the coming 20 years. ${ }^{[1]}$ According to the 2002 data, road injury-related deaths are ranked 11th among all causes of death and are foreseen to be third by $2020 .^{[1,2]}$
In the current situation, the fatality rate due to road traffic injuries in low- and middle- income countries are higher in comparison with the developed countries $(21.5,19.5,10.3$ per 100,000 persons, respectively), and despite the fact that $48 \%$ of the registered vehicles are in low- and middle-income countries, $90 \%$ of deaths occur in those countries. ${ }^{[3]}$ Especially in the last decades, while the number of vehicles has been rising rapidly, the number of occupants per vehicle is observed to be declining. This leads to a higher number of people being exposed to negative health effects. ${ }^{[4]}$ 
On a global scale, road traffic-related injuries are among the first 10 causes in terms of death and injury burden within the age groups of 0-4, 5-14 and 15-29. ${ }^{[5]}$ Road traffic-related injuries, which take an important place among injuries, attract attention due to the fact that adolescent and young adults are the most highly affected of all groups. It has been pointed out that children and adolescents have become the target group to be affected by injuries since the frequency of road traffic-related injuries in urban areas has risen. ${ }^{[6]}$

In parallel with the world, the situation in Turkey is somewhat similar. There have been significant increases in the number of vehicles, road traffic-related injuries and injuries in the last two decades (1980-2000). The number of vehicles has increased 7-fold while the number of injuries has increased more than 10-fold.

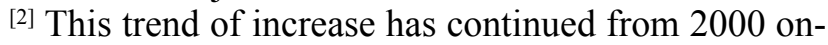
wards, and according to the data from the Turkish Statistical Institute (TSI), of the 14 million motor vehicles registered in $2007,10 \%(1,395,997)$ were involved in a road traffic accident and $12.9 \%$ of the road traffic accidents resulted in death and/or injury as a result of the 825,561 injuries. In these injuries, 5007 people died and 189,057 were injured. ${ }^{[7]}$

This study aimed to examine death and injury among the $0-17$ age group by studying the statistics related to road traffic-related injuries in Turkey.

\section{MATERIALS AND METHODS}

This study is a record-based assessment. The data upon which this assessment is based were obtained from the Annual Road Traffic Injury Statistics of the TSI. The TSI has been compiling the statistics concerning road traffic-related injuries since 1955. Road traffic injuries in Turkey are being recorded by two units that are subordinate to the Ministry of the Interior. These two units, each structured within their own regions accordingly, are the Gendarmerie and the General Directorate of Security.

In accordance with the legislation in Turkey, following the occurrence of a road traffic-related injury, the "record of traffic injury form", designed both for judicial and statistical purposes, is completed by both related units. Thus, following analysis of these forms by the TSI, the data of the annual statistics are compiled.

The assessment covers the period 2003-2007. From the data gathered in the annual statistics, the location of deaths and injuries and whether the injured/deceased was driver, passenger or pedestrian were studied with regard to their age groups. In these record books, it can be seen that ages were grouped as 0-5, 6-9, 10-14, and 15-17 in 2003, whereas ages were grouped as 0-9, $10-14$ and $15-17$ in 2004. Having compiled the age groups, this study is based on the age group of $0-17$ years.

Compiled by the TSI, the age range groups are presented only in the statistics of injuries falling under the jurisdiction of the General Directorate of Security. Statistics of injuries falling under the jurisdiction of the Gendarmerie do not present any age range distribution.

\section{RESULTS}

Data related to road traffic injuries are presented in Tables 1 and 2. Having considered these data, in spite of the more floating and slight increase in the numbers

Table 1. Total number of vehicles, road traffic accidents, deaths and injuries in selected years in Turkey

\begin{tabular}{ccccc}
\hline Years & Number of vehicles & Road traffic accidents & Total number of deaths & Total number of injuries \\
\hline 1980 & 1.334 .254 & 36.914 & 4.199 & 24.608 \\
1990 & 2.981 .222 & 115.295 & 6286 & 87693 \\
2000 & 7.161 .379 & 466.385 & 3.941 & 115.877 \\
\hline
\end{tabular}

Table 2. Statistics of road traffic injuries and vehicles in Turkey (2001-2007)

\begin{tabular}{ccccccccc}
\hline Year & $\begin{array}{c}\text { Registered } \\
\text { motor } \\
\text { vehicles }\end{array}$ & $\begin{array}{c}\text { Motor vehicles } \\
\text { involved in an } \\
\text { accident }\end{array}$ & $\begin{array}{c}\text { Total number } \\
\text { of road traffic } \\
\text { accidents }\end{array}$ & $\begin{array}{c}\text { Accidents } \\
\text { resulting in death } \\
\text { and injury }\end{array}$ & $\begin{array}{c}\text { Total } \\
\text { number } \\
\text { of deaths }\end{array}$ & $\begin{array}{c}\text { Deaths per } \\
100000 \\
\text { people }\end{array}$ & $\begin{array}{c}\text { Total } \\
\text { number } \\
\text { of injured }\end{array}$ & $\begin{array}{c}\text { Injuries per } \\
100000 \\
\text { people }\end{array}$ \\
\hline 2001 & 8.521 .956 & 767.358 & 442.960 & 66.243 & 4.386 & 6.4 & 116.203 & 169.6 \\
2002 & 8.655 .170 & 763.473 & 439.777 & 65.748 & 4.093 & 5.9 & 116.412 & 167.2 \\
2003 & 8.903 .843 & 795.260 & 455.637 & 67.031 & 3.946 & 5.6 & 118.214 & 168.3 \\
2004 & 10.236 .357 & 932.111 & 537.352 & 77.008 & 4.427 & 6.2 & 136.437 & 190.0 \\
2005 & 11.145 .826 & 1.055 .113 & 620.789 & 87.273 & 4.505 & 6.3 & 154.086 & 213.8 \\
2006 & 12.227 .393 & 1.232 .537 & 728.755 & 96.128 & 4.633 & 6.3 & 169.080 & 231.7 \\
2007 & 13.022 .945 & 1.395 .997 & 825.561 & 106.994 & 5.007 & 7.1 & 189.057 & 267.8 \\
\hline
\end{tabular}

Ref: Annual Records of Turkish Statistical Institute 2004-2007. 
Table 3. Death and injuries among 0-17 age group (2003-2007)

\begin{tabular}{lcccccc}
\hline Year & $\begin{array}{c}\text { Total no. } \\
\text { of deaths }\end{array}$ & $\begin{array}{c}\text { No. of deaths } \\
\text { under jurisdiction } \\
\text { of GDS (\%) }\end{array}$ & $\begin{array}{c}\text { No. of deaths } \\
\text { in 0-17 age group } \\
\text { under jurisdiction } \\
\text { of GDS (\%) }\end{array}$ & $\begin{array}{c}\text { Total no. of } \\
\text { injuries }\end{array}$ & $\begin{array}{c}\text { No. of injuries } \\
\text { under jurisdiction } \\
\text { of GDS (\%) }\end{array}$ & $\begin{array}{c}\text { No. of injuries } \\
\text { in 0-17 age group } \\
\text { under jurisdiction } \\
\text { of GDS (\%) }\end{array}$ \\
\hline 2003 & 3946 & $2.811(71.24)$ & $313(11.13)$ & 118.214 & $95.607(80.88)$ & $15.674(16.39)$ \\
2004 & 4427 & $3.081(69.60)$ & $371(12.04)$ & 136.437 & $109.889(80.54)$ & $17.942(16.33)$ \\
2005 & 4505 & $3.195(70.92)$ & $345(10.80)$ & 154.086 & $123.977(80.46)$ & $21.160(17.07)$ \\
2006 & 4633 & $3.365(72.63)$ & $341(10.13)$ & 169.080 & $135.754(80.29)$ & $22.043(16.24)$ \\
2007 & 5007 & $3.462(69.14)$ & $363(10.49)$ & 189.057 & $149.814(79.24)$ & $24.460(16.33)$ \\
Total & 22.518 & $15.914(70.67)$ & $1.733(10.88)$ & 766.874 & $505.152(65.87)$ & $101.279(20.05)$ \\
\hline
\end{tabular}

GDS: General Directorate of Security.

Table 4. Deaths among the 0-17 age group according to site of occurrence (residential versus uninhabited) in Turkey (2003-2007)

\begin{tabular}{lcccccc}
\hline Years & Residential area & $\%$ & Uninhabited areas & $\%$ & Total & $\%$ \\
\hline 2003 & 157 & 50.16 & 156 & 49.84 & 313 & 100.00 \\
2004 & 210 & 56.60 & 161 & 43.40 & 371 \\
2005 & 202 & 58.55 & 143 & 41.45 & 100.00 \\
2006 & 169 & 49.56 & 172 & 50.44 & 345 \\
2007 & 188 & 51.79 & 175 & 48.21 & 341 \\
Total & 926 & 53.43 & 807 & 46.57 & 100.00 \\
\hline
\end{tabular}

Table 5. Injuries among the 0-17 age group according to site of occurrence (residential versus uninhabited) in Turkey (2003-2007)

\begin{tabular}{lcccccc}
\hline Years & Residential area & $\%$ & Uninhabited areas & $\%$ & Total & $\%$ \\
\hline 2003 & 11.079 & 70.68 & 4.595 & 29.32 & 15.674 & 100.00 \\
2004 & 12.636 & 70.43 & 5.306 & 29.57 & 17.942 & 100.00 \\
2005 & 15.229 & 71.97 & 5.931 & 28.03 & 21.160 & 100.00 \\
2006 & 15.502 & 70.33 & 6.541 & 29.67 & 22.043 & 100.00 \\
2007 & 17.112 & 69.96 & 7.348 & 30.04 & 24.460 & 100.00 \\
Total & 71.558 & 70.65 & 29.721 & 29.35 & 101.279 & 100.00 \\
\hline
\end{tabular}

of death, the increase particularly in injuries stands out. A total of 22,518 persons died due to road traffic injuries during the period of this study (2003-2007). $70.7 \%(15,914$ persons $)$ of these deaths fell under the jurisdiction of the General Directorate of Security.

The age group of $0-17$ years, which is the scope of the study, represents $10.9 \%$ of the 15,914 total deaths (range: $10.1 \%-12.2 \%$ over the 5 -year period). The injuries stand out as having a higher ratio. Of all the injuries suffered, $65.9 \%$ were under the jurisdiction of the General Directorate of Security, and the age group of $0-17$ accounted for $20 \%$ of the total number (16.2\%-17.1\%) (Table 3).

Among the $0-17$ age group, $53.5 \%$ of deaths and $70.7 \%$ of injuries related to road traffic occurred in residential areas (Tables 4 and 5). Having studied the occurrence of death according to years, the mortality of the $0-17$ age group was almost equal between residential areas and uninhabited areas except in 2004-
2005. In these two years, the death occurrence in residential areas was observed to have been higher (56.6\% and $58.6 \%$, respectively). There was a similar tendency for injuries according to years. Two-thirds of the injuries among the $0-17$ age group occurred in residential areas.

Over the 5 -year period, $63.8 \%$ of the children who were killed due to road traffic accidents in residential areas were pedestrians, $24.6 \%$ were passengers and $11.6 \%$ were reported to have been the driver (Table 6). In uninhabited areas, these rates were defined as $13.6 \%, 81.6 \%$ and $2.7 \%$, respectively. When examined according to years, most deaths among drivers occurred in 2006 (20.7\%), among passengers in 2007 (30.9\%) and among pedestrians in $2003(70.1 \%)$, in residential areas. Although there are similar rates in terms of death in uninhabited areas in accordance with years, the numbers in 2007 were slightly higher.

There seemed to be a similar trend in injuries re- 
Table 6. Deaths due to road traffic accidents among drivers, passengers and pedestrians in the 0-17 age group according to site of occurrence (residential versus uninhabited) (2003-2007)

\begin{tabular}{|c|c|c|c|c|c|c|c|c|}
\hline \multirow[t]{2}{*}{ Years } & \multicolumn{4}{|c|}{ Residential area } & \multicolumn{4}{|c|}{ Uninhabited areas } \\
\hline & Driver (\%) & Passenger (\%) & Pedestrian (\%) & Total (\%) & Driver (\%) & Passenger (\%) & Pedestrian (\%) & Total (\%) \\
\hline 2003 & $8(5.10)$ & $39(24.84)$ & $110(70.06)$ & $157(100.00)$ & $4(2.56)$ & $125(80.13)$ & $27(17.31)$ & $156(100.00)$ \\
\hline 2004 & $14(6.67)$ & $51(24.29)$ & $145(69.05)$ & $210(100.00)$ & $1(0.62)$ & $138(85.71)$ & $22(13.66)$ & $161(100.00)$ \\
\hline 2005 & $26(12.87)$ & $40(19.80)$ & $136(67.33)$ & $202(100.00)$ & $5(3.50)$ & $113(79.02)$ & $25(17.48)$ & $143(100.00)$ \\
\hline 2006 & $35(20.71)$ & $40(23.67)$ & $94(55.62)$ & $169(100.00)$ & $5(2.91)$ & $145(84.30)$ & $22(12.79)$ & $172(100.00)$ \\
\hline 2007 & $24(12.77)$ & $58(30.85)$ & $106(56.38)$ & $188(100.00)$ & $7(4.00)$ & $154(88.00)$ & $14(8.00)$ & $175(100.00)$ \\
\hline Total & $107(11.56)$ & $228(24.62)$ & $591(63.82)$ & $926(100.00)$ & $22(2.73)$ & 675 (83.64) & $110(13.63)$ & $807(100.00)$ \\
\hline
\end{tabular}

Table 7. Injuries due to road traffic accidents among drivers, passengers and pedestrians in the 0-17 age group according to site of occurrence (residential versus uninhabited) (2003-2007)

\begin{tabular}{lccccccccc}
\hline Years & \multicolumn{4}{c}{ Residential area } & & \multicolumn{3}{c}{ Uninhabited areas } \\
\cline { 2 - 4 } & Driver (\%) & Passenger (\%) & Pedestrian (\%) & Total (\%) & & Driver (\%) & Passenger (\%) & Pedestrian (\%) & Total (\%) \\
\hline 2003 & $1.033(9.32)$ & $4.886(44.10)$ & $5.160(46.57)$ & $11.079(100.00)$ & & $59(1.28)$ & $4.349(94.65)$ & $187(4.07)$ & $4.595(100.00)$ \\
2004 & $1.287(10.19)$ & $5.805(45.94)$ & $5.544(43.87)$ & $12.636(100.00)$ & & $64(1.21)$ & $5.075(95.65)$ & $167(3.15)$ & $5.306(100.00)$ \\
2005 & $2.609(17.13)$ & $6.962(45.72)$ & $5.658(37.15)$ & $15.229(100.00)$ & & $91(1.53)$ & $5.633(94.98)$ & $207(3.49)$ & $5.931(100.00)$ \\
2006 & $2.903(18.73)$ & $7.372(47.56)$ & $5.227(33.72)$ & $15.502(100.00)$ & & $130(1.98)$ & $6.245(95.33)$ & $166(2.69)$ & $6.541(100.00)$ \\
2007 & $3.103(18.13)$ & $8.632(50.44)$ & $5.377(31.42)$ & $17.112(100.00)$ & & $126(1.71)$ & $7.047(95.90)$ & $175(2.38)$ & $7.348(100.00)$ \\
Total & $10.935(15.28)$ & $33.657(47.03)$ & $26.966(37.68)$ & $71.558(100.00)$ & & $470(1.58)$ & $28.349(95.38)$ & $902(3.03)$ & $29.721(100.00)$ \\
\hline
\end{tabular}

lated to road traffic accidents among the $0-17$ group (Table 7). Of those who were injured in the residential areas, $15.3 \%$ were drivers, $40.7 \%$ were passengers and $37.7 \%$ were pedestrians, whereas in uninhabited areas, injuries among passengers were higher (passengers $95.4 \%$, pedestrians $3.0 \%$ and drivers $1.6 \%$ ).

\section{DISCUSSION}

In general, the importance of death among children and adolescents is increasing especially in developing countries. A study carried out in Pakistan determined that $81 \%$ of injuries among this age group are caused by motor vehicles. ${ }^{[8]}$ Parallel with this, road traffic accidents in Turkey also seem to have increased in terms of deaths and injuries suffered in accordance with years. The number of road traffic accidents has risen 5 times from 1990 to $2004 .{ }^{[9]}$ This trend is more striking in terms of injuries suffered. In the early 2000 s, the total number of deaths per 100,000 persons was 6.4 and of injuries was 169.6, whereas these numbers were 7.1 and 267.8, respectively, in 2007. ${ }^{[10-13]}$ WHO data have indicated the number of deaths related to road traffic accidents as 11.5 per 100,000 persons. ${ }^{[14]}$

This study, based on data over a 5-year period, examined deaths and injuries among children under the age of 18 years. In this 5-year period, this age group represented $10.1 \%$ and $12.2 \%$ of deaths and $16.2 \%$ and $17.1 \%$ of injuries in the areas where statistics included the age distribution. From this point of view, these rates are observed to show similarities with other conducted studies. Hyder and his colleagues, ${ }^{[6]}$ in a large-scale assessment that examined the studies carried out in urban areas of South Asia, pointed out that child and adolescent deaths related to road traffic accidents accounted for $13 \%$ of all traffic-related deaths. In a study that compiled the data of sub-Saharan African countries, it was emphasized that $11 \%$ of all road traffic injuries are seen among the age group of under-19. ${ }^{[15]}$ The similarity of these rates in Turkey is similar despite its different regional characteristics. In a hospital-based study carried out in Turkey, it was seen that the $0-10$ age group accounted for $6.9 \%$ and the $11-20$ age group for $17.4 \%$ of all cases. ${ }^{[2]}$

In Europe, among the age group of under 15, the mortality of road traffic accidents indicates pedestrians as first $(48 \%)$ followed by passengers $(32 \%)$ and cyclists and their passengers $(8 \%)$. This profile changes in accordance with ages ${ }^{[4]}$ Comparing the results we obtained from our study with this data, the death occurrences among pedestrians in the scope of this study was higher than in Europe (63.8\%). The occurrence of death among passengers was more apparent in uninhabited areas (83.6\%).

The data on which this study has been based provides the age distribution as pedestrians, passengers and drivers; thus, it does not provide any further details such as cyclist, passengers in cars, buses, etc. It thus does not allow a detailed analysis and assessment. However, it is considered that the death occurrence among passengers is high in uninhabited areas due to the fact that car and bus injuries may occur more in 
these areas. According to the 2007 road traffic injury statistics of all the registered vehicles involved in road traffic accidents, $29.6 \%$ were buses, $20 \%$ minibuses, and $13.1 \%$ cars. Studying the vehicles involved in a road traffic injury causing death, cars rank first. ${ }^{[7]}$

A point of concern in the study is the death of drivers in the $0-17$ age group. In the residential areas, $11.6 \%$ of deaths and in uninhabited areas $2.7 \%$ of deaths were the drivers. These rates are $15.3 \%$ and $1.6 \%$ for injuries, respectively. According to the legislation in Turkey, a person must be over 18 years old to obtain a driver's license. When considered from this point of view, no adequate data have been acquired to explain the situation. Since the characteristics of deaths and injuries of drivers in accordance with their ages have not been detailed in the annual records examined, there would be no possibility of carrying out an assessment in terms of cyclist injuries, which may be casual analysis and explanatory factor. Studying the WHO data related to Turkey, deaths related to bicycles account for $2 \%$ of all deaths, yet it is unknown whether these deaths are among the age group of $0-17 \cdot \cdot^{[16]}$

As a result, it is thought that this might reflect deficiencies and inaccuracies in the records. In a study carried out in this regard, deaths caused by road traffic accidents were thought to number 8,000 , whereas the total number of deaths was 3,941 according to TSI data. ${ }^{[17]}$ This apparent difference might have been caused by the fact that the records include the deaths and injuries related to the site where the incident has occurred and that the records after the hospital transport could not be integrated. According to the results of a study carried out in the United States, $50 \%$ of all road traffic accident-related deaths occurred where the injury happened and $47 \%$ en route to or at the hospital. ${ }^{[17]}$

One of the main limitations of the study is that not all of the data have been covered due to the fact that age distribution is only taken into consideration in those cases under the jurisdiction of the General Directorate of Security. Results might have been affected due to the fact that $30 \%$ of deaths and $20 \%$ of injuries have been excluded from the scope of the study. However, it is not possible to predict the size of the effect. Both problems with the records and the mentioned limitations indicate that the problem might be greater than indicated by the figures reported in this study.

In conclusion, according to the statistics of the 5-year period examined, in terms of the road traffic in- jury statistics in Turkey, $11 \%$ of deaths and $20 \%$ of injuries occur among the $0-17$ age group. This is a public health problem in Turkey that requires precautions to be reconsidered for the mentioned age group and necessitates development of policies and programs. The development of solutions to this problem is a responsibility of the public.

\section{REFERENCES}

1. WHO. World Report On Road Traffic Injury Prevention, 2004, http://whqlibdoc.who.int/publications/2004/9241562609.pdf (Access date: December 2009).

2. Esiyok B, Korkusuz İ, Canturk G, Alkurt H, Karaman AG, Hanc1 İH. Road traffic accidents and disability: A crosssection study from Turkey. Disability and Rehabilitation 2005;27:1333-8.

3. WHO (2009). Global status report on road safety http:// whqlibdoc.who.int/publications/2009/9789241563840_eng. pdf. (Access date: December 2009).

4. WHO Regional Office for Europe. Economic valuation of transportrelated health effects Review of methods and development of practical approaches, with a special focus on children. http://www.euro.who.int/Document/E92127.pdf. (Access date: December 2009).

5. Hyder AA, Childhood injuries. Inj Prev 2003;9:292.

6. Hyder AA, Amach OH, Garg N, Labinjo MT. Estimating the burden of road traffic injuries among children and adolescents in urban South Asia. Health Policy 2006;77:129-39.

7. Traffic Accident Statistics Road 2007. Ankara: Turkish Statistical Institute (TSI) Publishing; 2009.

8. Razzak JA, Luby SP, Laflamme L, Chotani H. Injuries among children in Karachi, Pakistan-what, where and how. Public Health 2004;118:114-20.

9. Akgüngör AP. Road traffic accidents and safety programme in Turkey. Int J Inj Contr Saf Promot 2007;14:119-21

10. Traffic Accident Statistics Road 2006. Ankara: Turkish Statistical Institute (TSI) Publishing; 2008.

11. Traffic Accident Statistics Road 2005. Ankara: Turkish Statistical Institute (TSI) Publishing; 2007.

12. Traffic Accident Statistics Road 2004. Ankara: Turkish Statistical Institute (TSI) Publishing; 2006.

13. Road Traffic Accident Statistics 2003. Ankara: Turkish Statistical Institute (TSI) Publishing; 2006.

14. WHO. Estimated deaths per 100,000 population by cause, and Member State, 2004. http://www.who.int/healthinfo/ global_burden_disease/gbddeathdalycountryestimates 2004 . xls. (Access date: January 2010).

15. Hyder AA, Labinjo M, Muzaffar SS. A new challenge to child and adolescent survival in urban Africa: an increasing burden of road traffic injuries. Traffic Inj Prev 2006;7:381-8.

16. WHO http://www.who.int/violence injury prevention/road safety_status/country_profiles/turkey.pdf. (Access date: January 2010).

17. Naci H, Baker TD. Productivity losses from road traffic deaths in Turkey. Int J Inj Contr Saf Promot 2008;15:19-24. 